\title{
Interrelated Treaty Orders Across the Generations: Autonomy, Obligation and Confederacy in the Wabanaki Compact (1725-26)
}

\section{Andrew Costa*}

Throughout the $18^{\text {th }}$ century, the eastern Wabanaki peoples and the British Crown negotiated several Peace and Friendship Treaties, as well as Compacts, to properly situate the Crown among the Wabanki Confederacy (Mi'kmaq, Penobscot, Wulstukwiuk, Passamaqoddy). One treaty was the Wabanaki Compact of 1725-26. The agreements that comprised the Wabanaki Compact were negotiated in the years succeeding the Treaty of Utrecht (1713) and the Indigenous - Crown skirmishes and raids that culminated in Dummer's War (1722 - 25). This paper asserts the Wabanaki Compact (specifically Mascarene's Treaty) maintains legal import by showing that many components of the agreement actually contained Crown obligation to preserve customary religious observance and generational hunting, fishing and trapping rights. The Compact also builds up interdependent relations between the Crown and the Wabanaki that were premised on a strong responsibility to preserve and assist the well being of adjoined communities or nations. These assertions will be analyzed through the lens of Wabanaki legal teaching related to interrelatedness, generational obligation, linguistic protocols and gift giving ceremonies. Legal judgments like R v. Sappier \& Polchies and R v. Sappier; R $\mathrm{v}$. Grey show that the Crown is tied to these relations by recognizing their role in affirming their fidelity to the treaty order well into the future. Analyzing the Compact with these principles in mind implies that partners individually hold normative autonomy while also collectively holding obligation to preserve living treaty partnerships throughout future generations. It is argued that the Wabanaki Compact also retains legal relevance by tying the Crown and the Wabanaki (specifically the Mi'kmaq and Wulstukwiuk) in intergenerational obligation through respecting and preserving the autonomy which brought them to the Compact in the first place.

Tout au long du XVIII siècle, les Wabanakis de l'Est et la Couronne britannique ont négocié plusieurs traités de paix et d'amitié, ainsi que des pactes, afin de bien situer la Couronne au sein de la confédération Wabanaki (Micmacs, Penobscot, Maliseet, Passamaqoddy, Abénaquis). Des traités comme le Wabanaki Compact (pacte des Wabanaki de 1725) (que les Micmacs ont ratifié en 1726) ont marqué le début pour la

\footnotetext{
I would like to acknowledge the influence that both L. Jane McMillan and Romola Thumbadoo have had in inspiring the completion of this paper. Their guidance and support have been truly valuable when researching, presenting and writing this paper. I would like to thank the internal and external reviewers at the Windsor Yearbook of Access to Justice for the excellent suggestions to make the paper, its structure and arguments more effective than originally imagined. As a non Indigenous person I wish to sincerely thank Indigenous writers and activists as well as the histories and the traditions passed down to them. Engaging with this work has been hugely influential in my desire to learn more of the aweinspiring complexity on which Indigenous legal traditions are based. The research and writing of this article have been completed during my ongoing PhD study at Carleton University in the Department of Law and Legal Studies.
} 
Couronne d'un ordre axé à la fois sur l'autonomie et l'indépendance. Dans ce contexte, la Couronne a été appelée à jouer un rôle de protectorat à l'endroit des collectivités de la confédération Wabanaki en respectant et en protégeant leur intégrité territoriale, leurs traditions fondées sur la coutume et les protocoles qui les régissent. Ce rôle de protectorat devait être élargi au fil des générations. En échange, la Couronne avait le droit de recevoir des territoires octroyés au nom des Wabanakis. Qui plus est, les Wabanakis devaient s'abstenir de nuire à la sécurité sur les territoires en question, que ce soit dans le cadre d'un conflit armé ou autrement. Dans ce texte, l'auteur soutient que l'idée d'autonomie prônée dans le pacte des Wabanakis est préservée par la reconnaissance des liens entre ces peuples et les ordres collectifs, écologiques et cosmologiques constituant le fondement de leurs protocoles et coutumes traditionnels sur lesquels repose leur interdépendance. Ce postulat sera analysé sous l'angle des enseignements juridiques des Wabanakis concernant l'interdépendance, de l'obligation générationnelle, des protocoles linguistiques et des cérémonies de don de cadeaux. Il est impératif de transmettre les connaissances relatives à ces fondements d'une génération à l'autre de manière à assurer la pérennité de ces liens. Dans le cadre de son rôle de protectorat, la Couronne se doit de tenir compte de ces liens en reconnaissant constamment leur importance pour préserver tant les fondements des traités que les relations

\section{INTRODUCTION}

The Wabanaki Compact (hereinafter Compact) comprises two treaties and additional ratification agreements between North Atlantic Indigenous peoples and the British Crown (hereinafter the Crown). These agreements, known as Dummer's Treaty and Mascarene's Treaty ${ }^{1}$ respectively, created partnerships throughout territories in Massachusetts (and Maine) as well as in what is presently Eastern Canada. Treaty making in the early $18^{\text {th }}$ century hardly implied a singular engagement where Crown and Indigenous delegations would immediately reach similar conclusions regarding proposed agreements. The Wabanaki (Mi'kmaq, Wulstukwiuk, Passamaquoddy and Penobscot) tribes throughout the region had contrasting goals and motivations that came with participating in the new treaty order. Completing any treaty highly depended on the Crown being able to respond to this diversity. For instance, Patterson argues that the Penobscot envoys "...made it clear in their meetings in Boston in November 1725 that their land questions must be resolved. In this they had no intention of speaking for (the) Mi'kmaq of Nova Scotia or negotiating for any natives besides themselves." 2

Conversely, the Nova Scotia agreements including the Mi'kmaq and Wulstukwiuk (Maliseet) contained provisions that strongly differed from the earlier treaties agreed to by the Penobscot. Nicholas also writes 'For example, (the Penobscot) Dummer's Treaty allows settlers to return to all former English settlements on Native lands in what is now Maine, but carefully disallows any new settlements. However, the (Mi'kmaq and Wulstukwiuk) Mascarene version requires Natives to respect both existing and future

1 These agreements were named after the Lieutenant Governor of Massachusetts William Dummer and the Lieutenant Governor of Nova Scotia Paul Mascarene.

2 Supra note 8 at 54. 
English settlements in Nova Scotia." ${ }^{3}$ With these differences in mind, some have also gone on to argue Mascarene's Treaty could hardly be a treaty at all. ${ }^{4}$ It has been argued the treaty lacks legal relevance given the divergence between it and Dummer's Treaty as well as the ensuing armed engagements that emerged after the agreement's completion.

The contentious histories surrounding the Wabanaki Compact and its later agreements are believed to leave them excluded from the Indigenous and treaty rights regime maintained in Canada's constitution ${ }^{5}$. Nevertheless, many have also argued that the order inaugurated by the Wabanaki Compact actually captures the intergenerational partnerships that treaties encourage. This is guaranteed through an obligation that treaty parties are to respect and protect their partners' autonomous well being through succeeding generations.

This is displayed in Mascarene's Treaty whereby the Wabanaki tribes' cultural customs and traditional access to hunting, fishing and trapping sites were to be maintained for all time. Therefore, contrary to the assertion that the Mi'kmaq and Wulstukwiuk ignored treaty conditions through engaging in additional skirmishes, this paper argues that the Wabanaki Compact (particularly Mascarene's Treaty) retains legal relevance by tying the Crown and the Wabanaki (specifically the Mi'kmaq and Wulstukwiuk) in intergenerational obligation through respecting and preserving the autonomy which brought them to the Compact in the first place.

This paper proceeds by looking at some key tenets of Wabanaki legal teaching. These include loyalty to the interrelated order, especially through preserving its abundant bounty across the generations. The role that verb-based, Eastern Algonquian languages play in comprehending this order and their role in educating others is also mentioned. ${ }^{6}$

The paper follows with an analysis of key historical precursors to the Wabanaki Compact. The Crown's expansion into the French stronghold over the Eastern Canadian and Atlantic coast is highlighted. One key precursor to the Compact was increasing Crown expansion in the region through the capture of the Acadian military garrison at Port Royale, and the renaming of it as Port Annapolis, in 1710. The capture eventually led to the Treaty of Utrecht in 1713. The Treaty of Utrecht was initially completed with the intent to expand Crown authority in Acadia, controlling the region so as to guarantee greater expansion into what is presently Eastern Canada. These expansionary goals inevitably ran counter to concerns about increased settlement and its residual impacts on Wabanaki groups' ability to maintain customary livelihoods. These divergent concerns eventually led to armed engagements between the Crown and Wabanaki tribes that took place throughout the region comprising present day New Hampshire through to Nova Scotia. The resulting skirmishes with Wabanaki groups throughout the region both preceeding and succeeding the capture of Port Royale and its sanction in the Treaty of Utrecht are reviewed in some detail as well.

3 Andrea Bear Nicholas, "Mascarene's Treaty of 1725" (1994) 43 U.N.B.L.J [Nicholas, "Mascarene's Treaty"] at 3

4 Additional articles that allude to the Wabanaki Compact being declared invalid in test cases are: John P. McEvoy,

"Aboriginal Activities and Aboriginal Rights: A Comment on R v. Sappier; R v. Grey" (2007) 6 Indigenous Law Journal 2 (HO) as well as Guy C. Charleton, "Letting Go of Culture: A Comment on $R$ v. Sappier; $R$ v. Grey (2007) 39 Ottawa L. Review 2 (HO).

5 s. 35 (1) of the Constitution Act 1982 reads "The existing aboriginal and treaty rights of the aboriginal people in Canada are hereby recognized and affirmed."

6 Naiomi Metallic, "Becoming a Language Warrior" in Marie Battiste, eds, Living Treaties: Narrating Mi'Kmaw Treaty Relations (Sydney, NS: Cape Breton University Press, 2016) 241. 
The paper then shows how the skirmishes and raids reached their climax in in the 1720s and how the eventual Wabanaki Compact emerged through recognition of the military and planning capacity displayed by the Wabanaki. While armed skirmishes between Wabanaki tribes and the Crown had taken place throughout the Northeastern Atlantic region since the late $17^{\text {th }}$ century, major military engagements emerged in the years succeeding the Treaty of Utrecht through to the early 1720s. These culminated in a series of skirmishes and boating raids that later became known as Dummer's War. William Wicken writes "The (Dummer's) War lasted about three years, from 1722 to 1725 , and occurred as a result of an expansion of New England settlements along the Kennebec River and of the movement of more New England fishermen into Nova Scotia waters. Neither (Mi'kmaq and Wabanaki) had been consulted. Neither were amused. And neither reacted passively to New England's aggression."7

Throughout the armed engagements, however, the Crown grew to believe that continually ignoring Wabanaki interests in the region was to their tactical detriment given the military capacity these groups possessed. Patterson also points out "At least until the eighteenth century, natives had both the numerical and physical strength to resist European intrusion. They made reasoned choices about how to deal with their relationships, drawing on a tradition of self-reliance and self-governance in doing so." 8 With this recognition of Wabanaki strength, the Crown proceeded to dispatch delegations to villages across the region, so as to signal their intentions to engage in treaty negotiations with the Wabanaki.

The contrasting obligations in the resulting Dummer's Treaty and Mascarene's Treaty are pointed out as well. Moreover, the recurrent skirmishes that took place between the Mi'kmaq/Wulstukwiuk and the Crown, and how they apparently left the Mascarene's Treaty component of the Wabanaki Compact null and void are highlighted as well. Also included is Stephen Patterson's assertion that the divergence between treaty stipulations in Dummer's and Mascarene's agreements as well as the conflicts between the Wabanaki and the Crown apparently delayed Mi'kmaq and Wulstukwiuk involvement in the treaty order for another quarter century. Patterson also goes on to argue "There is no historical basis for arguing that the treaties of 1725-26 'existed' in 1982, as required by section 35 of the Constitution." 9 This leaves Mascarene's Treaty as a mere curiosity left to history and stripped of any legal value. This also apparently leaves present day Mi'kmaq and Wulstukwiuk groups largely unable to appeal to the Compact for legal guarantees to hunt and trap on their customary territories.

Following this section is an analysis of Patterson's argument that the treaties succeeding the Wabanaki Compact are granted their legal legitimacy only through the total acquiescence of the Wabanaki peoples to conditions determined by the Crown. This section also highlights Patterson's argument that the Crown was only obligated to regard the Wabanaki as equal subjects in their common law polity. For instance, in the later Peace and Friendship Treaties of 1760-61, Patterson writes "Neither side sought to turn back

7 Willam C. Wicken, "Mi'kmaq Decisions: Antonie Tecouenemac, the Conquest and the Treaty of Utrecht" in John G Reid, et al., eds, The 'Conquest' of Acadia, 1710: Imperial, Colonial and Aboriginal Constructions (Toronto, ONT: University of Toronto Press, 2004) [86] at 96-97.

8 Stephen E. Patterson, “Anatomy of a Treaty: Nova Scotia’s First Native Treaty in Historical Context” (1999) 48 U.N.B.L.J 41 (HO).

$9 \quad$ Supra note 8 at 64. 
the clock to 1500 . Native people did not ask to be left alone or to define their relationship with the British in terms of two solitudes." 10

It is shown Patterson's assertions are problematic largely because they advance a troublesome all or nothing outcome regarding the Wabanaki Compact. In Patterson's view, the outcomes either left the Wabanaki to agree to the treaties and assent to absolute Crown authority in their homelands or violate treaty conditions (or not sign at all) and "turn the clock back to 1500" in solitude. By contrast, Nicholas points out that in the Wabanaki Compact, Crown obligation "...to respect Aboriginal access to fish and game in Nova Scotia, (is) not an English-given right, but an English obligation to recognize and respect the pre-existing and continuing reality of Aboriginal survival derived from the land and its resources." 11 It is then shown that in the Compact, Wabanaki tribes actually wished to maintain their autonomy while also looking to develop a long lasting partnership with the Crown, where each party would respect and protect each other's autonomy in the treaty order throughout the generations.

Many analyses are taken up to support the assertion that the Wabanaki role in treaty negotiations with the English was not premised on an 'all or nothing' choice between accepting Crown authority or living in autonomous solitude. Andrea Bear Nicholas argues that when probing the entire treaty record besides Mascarene's Treaty, it is clear that obligation entailed a great deal more than Mi'kmaq and Wulstukwik acquiescence to both pre-existing and subsequent Crown settlement. This is especially the case in additional agreements like Mascarene's Promises which contain "... several of the original articles to be demanded of the Indians turned into promises or listed with added rewards for their fulfillment."12

In legal judgments like $R v$. Peter Paul ${ }^{13}$ and $R v$. Sappier and Polchies ${ }^{14} \mathrm{Mi}^{\prime} \mathrm{kmaq}$ and Wulstukwik groups have advanced arguments asserting a continued right to hunt, fish and trap in their customary homelands as guaranteed in the Wabanaki Compact. These arguments are highlighted to show that larger treaty and historical records existing alongside the Mascarene's Treaty guarantee the Mi'kmaq and Wulstukwik the autonomy to maintain traditional harvesting practices and cultural rights. Moreover, Nicholas argues that "The existence of Mascarene's Promises is incontrovertible evidence that colonial authorities in Nova Scotia were prepared at the time to make a legitimate treaty." ${ }^{15}$ To this end the paper uses relevant case law and key historical analyses to show that the Wabanaki Compact (Mascerene's Treaty specifically) was not completed in an "all or nothing" setting whereby the Mi'kmaq and Wulstukwik had chosen between totally complying with Crown interests in exchange for recognition as common law subjects or a solitude that wished to ignore the Crown altogether.

10 Stephen Patterson, "Eighteenth-Century Treaties: The Mi’kmaq, Maliseet, and Passamaquoddy Experience" (2009) 18 Native Studies Review 51.

11 Nicholas, "Mascarene's Treaty", supra note 4 at 12.

12 Ibid at 9.

$13 \quad R$ v. Peter Paul, 199812246 (NB CA).

14 R v. Sappier and Polchies, 2004 NBCA 56.

15 Nicholas, "Mascarene's Treaty", supra note 4 at 10. 


\section{INTERRELATED OBLIGATION ACROSS WABANAKI LIFEWORLDS}

\section{A. Customary Obligation}

Appreciating the value that Wabanaki communities bestow (to this day) on the Wabanaki Compact implies respecting the connected obligations that structure relations throughout the Dawnland region. ${ }^{16}$ Many have argued these connections emerge through eternal ecological and cosmological relationships whereby communities develop an awareness of generational obligations to the world around them. ${ }^{17}$ In analyzing Anishinaabek teaching, Aaron Mills writes that placement in a symbolic order involves an awareness of "...ontological, cosmological, and epistemological understandings which situate us in creation and thus which allow us to orient ourselves in all our relationships in a good way. Without having begun to internalize our lifeworld, one has no hope of understanding our law." 18 Henderson regards Mi'kmaq orders as being built up by a cognitive solidarity among all life. This solidarity inspires a normative legal order that, as he writes: “...emphasized the flux of the world, encouraging harmony in all relationships. This was the center of their legal institutions and heritage. It reflected their belief that the world was made in accordance to an implicit design that could be at least partially apprehended and enforced by them."19

Mi'kmaq and Wulstukwiuk conceptions of obligation emerge through individuals collectively preserving their relations across existence. This also implies a desire to preserve those links through later generations. Ulrich \& Gill, in an imagined dialogue involving the Wabanaki hero and trickster Klooscap, write "By observing the ways of the land and living closely with all the nations within it - plant, animal, and human - our people have developed legal principles that allow us to make decisions that ensure our survival on the land on which we depend." ${ }^{20}$ Metallic also points out interdependent correlations among the Mi'kmaq have always inspired living treaties which maintain their obligations to the world. ${ }^{21}$ These relations imply an understanding of how everything is tied to welfare beyond individual well being.

\section{B. Stewardship Obligation}

The traditional Mi'kmaq stewardship concept known as Netukulimk is a valuable concept to learn about when comprehending how obligation emerges through interrelated existence. Prosper et al. point out that "Netukulimk is a complex cultural concept that encompasses Mi'kmaw sovereign law ways and individual and collective beliefs and behaviors in resource protection (and) procurement (for the) future

16 Dawnland is the English translation of Wabanaki. The term can also mean "People of the Dawn" given their homelands being situated on the Eastern Atlantic Coast.

17 Fred Metallic, “Treaty and Mi' gmewey" in Marie Battiste, eds, Living Treaties: Narrating Mi'Kmaw Treaty Relations (Sydney, NS: Cape Breton University Press, 2016) 42.

18 Aaron Mills, “The Lifeworlds of Law: On Revitalizing Indigenous Legal Orders Today" (2016) 61 McGill L.J., 847 $(\mathrm{HO})$.

19 James (Sakej) Youngblood Henderson, "Mi' Kmaw Tenure in Atlantic Canada" (1995) 18 Dalhousie L.J., 196 (HO).

20 Lara Ulrich and David Gill, "The Tricksters Speak: Klooscap and Wesakechak, Indigenous Law and the New Brunswick Land Use Negotiation” (2016) 61 McGill L.J., 979.

21 Metallic, supra note 13 at 46. 
generations." ${ }^{22}$ Some have asserted ${ }^{23}$ that the Mi'kmaq have typically regarded Netukulimk as an obligatory protocol meant to preserve and sustain peaceful relations constantly at work across existence. Furthermore, Netukulimk, according to Mi'kmaq elders, “.... is about respect, reverence, responsibility and reciprocity. Its practice and philosophy embrace co-existence, interdependence and community spirit." 24 Netukulimk implies that preserving human, animal, plant and spiritual existence maintains relations across the generations.

Netukulimk implies that individuals only appropriate what is essential in order to preserve relational well being by having enough so as to allow generations to continue to preserve the order. Expanding on this point, Patrick J. Augustine argues that Netukulimk implies "... an understanding to take only what was needed and to leave for rejuvenation and regrowth." ${ }^{25}$ Augustine continues "The Mi'kmaw law on harvesting applied to the annual food cycles of the seasons and involved certain protocols. These protocols were not to be breached for fear of offending the animal spirits for they might not return." ${ }^{26}$ For instance, appropriating too many eels may not allow the animal to properly procreate and add to its ecosystem. Reducing the eel population may also place great strains on an entire community to catch or consume them for its own extended family. With these relations in mind, Henderson contends that the Mi'kmaq "...believed that orderly processes presupposed and evoked balance in the soul and the environment" 27 while also implying that "...the self tended to be seen as an integral part of the family and ecosystem, rather than as an independent entity." 28

\section{Linguistic Obligation}

Through generations, the commitment to preserving relationships across existence is carried through oral histories. Customary stories and songs are invaluable in showing what individuals owe to the world that preserves their well being. Tuma Young asserts “The L'nuwey (Mi'kmaq word for Indigenous person) worldview can be found not only when- and wherever the language is spoken, but when- and wherever two or more L'nu come together in mutual understanding of the sacred realms of Mi'kma'kik." ${ }^{29}$ Henderson describes Mi'kmaq territory as a langscape ${ }^{30}$ through which language is linked to the surrounding environment. Throughout Wabanaki villages, relations between languages and the surrounding environment build upon " ... an evidential verbal system in nature, meaning its verbal systems code for the relational source of the speaker's and listener's 'knowledge experience', as opposed to the nature of the event." ${ }^{\text {"1 }}$ Langscapes are interplays of shifting relationships across existence and the

22 Kerry Prosper et al, "Returning to Netukulimk: Mi’ Kmaq Cultural and Spiritual Connections with Resource Stewardship and Self-Governance" (2011) 2 Int Indigenous Pol Journal 4.

23 McMillan \& Prosper, supra note 4 at 630, Augustine supra note 3 at 52.

24 McMillan \& Prosper, supra note 4 at 641 .

25 Augustine, supra note 4 at 55.

26 Ibid at 55.

27 James (Sakej) Youngblood Henderson, “First Nations Legal Inheritances in Canada: The Mi’ Kmaq Model (1995) 23 Man L.J., 1 (HO).

28 Henderson, supra note 24 at 15.

29 Tuma Young, L' nuwita' simk: A Foundational Worldview for a L' nuwey Justice System (2016) 13 Indigenous L.J., 75.

30 Henderson, supra note 15 at 225.

31 Young, supra note 26 at 81. 
reflexive languages that describe those relations. Henderson points out the generational value imbued in langscapes by writing "Aboriginal people talk about past experiences motivated by specific concerns, for example, the snow blinding moon. Objects come and go, but places in the sacred space continue as essential to explanation and description." 32 In essence, verb centered languages are describing processes at work, rather than noun based descriptions that represent relations as fixed.

Languages capture the interrelated obligation to the continued welfare of all life through the generations. It is also regarded as a descriptive device to comprehend ties between individuals as well as communities, ecologies and cosmologies. Langscapes are additionally premised upon a shared worldview in which individuals learn of their inherent placement in the interrelated order. Henderson writes that "To understand the order, one must live within it. Belonging is tied to spaces that make up their own consciousness, spaces that extend throughout the community to their experiences with the land. These experiences are not lifeless terms connected to landscape features; they describe the land or its character or common resources." 33

Mi'kmaq hereditary chief Stephen Augustine also points out the role language plays in articulating obligation through all generations. He mentions that "the language has a precise etymology and describes every known living entity - their internal organs, birthing patterns and growing cycles." ${ }^{4}$ Languages also maintain obligation through consensus-based decision making among diverse communities. For instance, among the Wulstukwiuk, Nicholas writes that

This dispersal of decision-making among both men and women in traditional Maliseet society is certainly confirmed by any knowledge of our culture and history. It shows up in our language, which has no gender. It shows up in our terms of kinship which, for the most part, are precisely the same for maternal relatives as for paternal relatives, indicating a means of reckoning lineage and relationships that is neither patriarchal nor matriarchal, but bilateral. ${ }^{35}$

Language serves an incalculably valuable role when determining how humanity is tied to the interrelated order as protectorates and beneficiaries. Languages go beyond the written word and into an imperative of communal obligation to the surrounding world. ${ }^{36}$

\section{Confederate Obligation}

Cultivating treaties and compacts was not new to the Wabanaki Confederacy when the Wabanaki Compact was negotiated. Metallic argues that, prior to relations with the Crown, "our (Mi'kmaq) creation story teaches that our first treaty establishes a relationship with the animals, while the second recognizes

32 Henderson, "Tenure", supra note 20 at 223.

33 Ibid at 221.

34 Augustine, supra note 4 at 55.

35 Andrea Bear Nicholas, "Colonialism and the Struggle for Liberation: The Experience of Maliseet Women (1994) 43 U.N.B.L.J., 223.

36 "Physical treaties" imply the actual material on which the treaties were signed without reference to customary protocols that informed negotiation and ratification. They also primarily refer to the written means which treaties would have normally been evaluated by Crown officials. 
a treaty with water beings. The first treaty orders land tenure, while the second treaty establishes a water tenure system. ${ }^{37}$ Furthermore, when coming together in creating the Wabanaki Confederacy, each nation adapted customary governing teaching to encourage peaceful relations between groups. Metallic argues these customary orders in the Wabanaki Confederacy encompass " ...the teachings of respect, peace, reciprocity, sharing and caring (and how they) remain central to our way of life, and how we govern in our territory." 38

Confederate, nation-to-nation ties were premised on a strong commitment to collectively preserve and assist the well being of associated groups. Prince Edward Island Premier Wade MacLauchlan points out "From the early 1680 s to the mid $1880 \mathrm{~s}^{39}$ the Wabanaki Confederacy worked to shape policies in reaction against -or in accord with- strategic movements by the French, English, Huron, Ottawa, Mohawk, Ojibwa and Iroquois. Their collaboration was based in a sacred bond of Algonquian goodwill, and reinforced by a sense of necessity." ${ }^{\prime \prime 0}$ These necessary bonds greatly impacted early relations with both English and French colonial powers.

\section{HISTORICAL PRECURSORS TO THE WABANAKI COMPACT}

\section{A. British Engagement on the Atlantic Coast}

The Crown initially settled in the Atlantic region through Henry VII granting John Cabot the authority (devolved by the Catholic Church through Papal Bulls) to settle the region. ${ }^{41}$ This led to the Crown reaching what is currently Newfoundland in 1497. English settlement, however, truly ramped up during the reign of Elizabeth I. Kolodny argues that Elizabeth I largely expanded the Crown's authority to settle the Atlantic region. ${ }^{42}$ Crown settlement was never more encouraged than when Elizabeth I did away with Papal Bull Decrees that limited expansion in regions that were already visited by Christians. Elizabeth I instead ruled that prospective Crown settlements could be limited only when territory was directly settled by a Christian monarchy. Kolodny specifically argues that "As first formulated by the Church, such phrasings functioned within the larger discourse of discovery to effectively eradicate Indigenous sovereignty by asserting legalistic and religious justifications for undoing the indivisible relationship

37 Metallic supra note 15 at 46.

38 Ibid at 50.

39 During the last 30 years the Wabanaki Confederacy has been reformed and recognized through annual ceremonies across the Dawnland.

40 H. Wade MacLauchlan, "Maritime Coopoeration: A Unique Runway and an Urgent Need to Take off" (2016) 67 U.N.B.L.J., 36. (HO).

41 Indigenous communities in what is presently Atlantic Canada (as well as the Northeastern United States) had engaged in trading activity with Europeans long prior to the English and French conflicts that led to Dummer's War and ultimately the Wabanaki Compact. Reports taken during the $16^{\text {th }}$ and $17^{\text {th }}$ centuries show that Mi'kmaq and Wulstukwik tribes had been major players in the Atlantic Cod trade with Iberian merchants.

42 Nevertheless, French explorers Samuel de Champlain and Marc Lescarbot were accompanied by Catholic Jesuits upon reaching the Atlantic Coast in 1607. The Acadian Port Royal was established shortly thereafter. Many Catholic Acadian priests either directly engaged with Mi'kmaq and Wulstukwik groups or they had learned about them through other settlers. 
between land and people." 43 Throughout several decades, the Crown looked to expand upon their existing settlements in Newfoundland and the New England regions through what is presently Maine, Massachusetts and New Hampshire. These goals were met with Wabanaki, French and Acadian resistance.

As mentioned earlier, the Crown engaged in skirmishes with Wabanaki warriorsthroughout the Atlantic and New England regions well prior to Dummer's War. McLay writes that during the late $17^{\text {th }}$ century King Philip's War, ${ }^{44}$ "the Wabanaki had been reluctant to involve themselves but, having been goaded into war by the colonists' export to the northern regions, they rigorously upheld the strategic sovereignty of their territory by expelling the English from the area northeast of Falmouth." 45 These conflicts led to treaty agreements between New England colonists and the Wabanaki throughout the late $17^{\text {th }}$ century. These agreements included a 1678 Peace Treaty and a succeeding Treaty of 1685. These agreements were to guarantee Penobscot and Passamaquoddy autonomy in the region. In actuality, however, these agreements hardly provided a guarantee that these tribes could lay a claim to customary territory.

The skirmishes that succeeded King Phillip's War created more conflict that further placed the Crown against tribal groups throughout the New England region. Delucia argues these conflicts persisted because of "dubiously legal land deeds and territorial erosion; religious pressures to convert from traditional ways to Protestant Christianity; an English court system that rendered justice asymmetrically for Natives and Englishmen; undermining tribal sovereignty by colonial authorities." 46 Moreover, the commitment to upholding treaty obligation ran up against increasing settlement in what is presently Maine and later Atlantic Canada. This led to armed retaliation by Wabanaki warriors. The retaliation halted widespread Crown settlement across the northeast. Ghere and Morrison argue resistance to these expansionary goals invariably led to strategic Crown settlement in areas that were not densely populated so as to avoid additional conflict. They write "The success of Abenaki ${ }^{47}$ raiding parties in the 1670 s and 1690s elicited both fear and some level of respect from colonial officials and frontier residents alike. This concern over Abenaki military power resulted in wholesale abandonment of frontier settlements in Maine during those hostilities." 48 These armed engagements were mirrored throughout what is presently Atlantic Canada.

\section{B. English Takeover of Acadia}

Armed conflicts between the Crown and the Mi'kmaq/Wulstukwik were very similar to those already involving their Wabanaki neighbors in New England. Armed engagements with the Crown were highly encouraged by the French given earlier social and religious ties between the two. Crown-Indigenous conflict in what is presently Atlantic Canada developed during the late $17^{\text {th }}$ century because as Wicken writes "...the number of (English) vessels increased after 1660, so too did contacts with Eastern Coast

43 Annette Kolodny, “'This Long Looked For Event': Retrieving Early Contact History from Penobscot Oral Traditions" (2015) 2 Native American and Indigenous Stud 96.

44 Which took place place between 1675 and 1678.

45 K.A.J. McLay, “Wellsprings of a 'World War': An Early English Attempt to Conquer Canada during King William's War, 1688-97 (2006) 34 Jour of Imp and Commonweal His 158.

46 Christine M. Delucia, "Locating Kickemuit: Springs, Stone Memorials, and Contested Placemaking in the Northeastern Borderlands" (2015) 13 Early American Studies 481 (PM).

47 Indigenous peoples in what is presently Maine.

48 David L. Ghere and Alvin H. Morrison, "Searching for Justice on the Maine Frontier: Legal Concepts, Treaties and the 1749 Wicasset Incident" (2001) 25 The Amer Ind. Quart 379 (380). 
Mi'kmaq. This occurred for a number of reasons. Fishermen sailed into harbor because of rough seas or because their vessels needed repair." 49

The Crown also took part in engagements with the Mi'kmaq and Wulstukwiuk because earlier military catastrophes against the French left Governors with the singular strategy of taking part in armed skirmishes with the Wabanaki throughout what is presently Atlantic Canada. McLay points out that "Laboring under straitened financial circumstances, and without more material and strategic commitment from England, the North American colonists could only promote a defensive war of frontier skirmishes against the Indians. ${ }^{, 50}$ Defensive skirmishes between the Crown and the Mi'kmaq/Wulstukwiuk (as well as their continued encouragement by the French) went to create a hostile environment throughout Atlantic Canada that persisted throughout the early $18^{\text {th }}$ century.

The French not only encouraged armed engagements but they eventually grew to heavily rely upon Wabanaki communities, especially as the Crown greatly expanded throughout the region. Carroll points out the extent to which the colonial powers relied upon Indigenous warriors by arguing that "During the early imperial wars in the region (1689-1726) Algonquians usually served in the army in tribal units or all-Indian ranger companies specializing in reconnaissance and guerilla warfare. Indian soldiers constituted as much as 20 percent of troops on major campaigns. ${ }^{.1}$ In order to disrupt the Crown's growing reach, Wabanaki warriors also engaged in many Winter raids upon English frontier towns particularly during the latter $17^{\text {th }}$ and early $18^{\text {th }}$ century. ${ }^{52}$ Wickman writes "The Winter of 1703-04 brought severe cold and a series of Wabanaki raids. Small attacks resulted in three English deaths and two captives at Saco, four killed and two wounded at Casco, one dead and one wounded in Berwick, and thirteen killed and five captured at Haverhill." ${ }^{53}$

The French Crown and its Jesuits encouraged skirmishes between Wabanaki warriors and the English because supporting Indigenous authority over their customary territories helped to create a strategic barrier between newly obtained English territory in Acadia and French territory in Quebec. In accepting military support, however, Wabanaki tribes were not passively loyal to French interests. ${ }^{54}$ This is largely because they were highly dismayed with the French Crown ceding landed interests to the English in the Treaty of Utrecht, especially when the French were always looked upon as guests in their homelands. ${ }^{55}$

Dummer's War brought on boating raids that were to greatly impact the Atlantic cod trade. Wicken continues by writing "In 1715 and again in 1720, Mi'kmaq chiefs told the governor of Ile Royale of their displeasure at the number of New Englanders fishing along the coast. In August 1720, the Mi'kmaq and

$49 \quad$ Wicken supra note 2 at 14.

50 McLay supra note 47 at 170.

51 Brian D. Carroll, "The Effect of Military Service on Indian Communities in Southern New England, 1740-1763" (2016) 14 Early American Studies 510.

52 Wickman writes that prominent Winter raids took place during 1689-90, 1691-92, 1696-97 and 1697-98.

53 Thomas Wickman, “'Winters Embittered With Hardships': Severe Cold, Wabanaki Power, and English Adjustments, 1690-1710" (2015) 72 The Will and Mary Quart 85.

54 Read Saliha Belmessous "Wabanaki versus French and English Claims in Northeastern North America" in Saliha Belmessous eds., Native Claims: Indigenous Law against Empire 1500 - 1920 (Toronto ONT: Oxford University Press).

55 Read John G. Reid "Imperialism, Diplomacy and the Conquest of Acadia" in John G. Reid et al. eds., The Conquest of Acadia, 1710 Imperial, Colonial, and Aboriginal Constructions (Toronto ONT: University of Toronto Press) 101. 
their Wabanaki allies attacked New Englanders fishing at Canso." 56 Raids were also initiated by the Mi'kmaq and Wulstukwik throughout the Massachusetts coast during the war's most intense period. Responding to these attacks, Wicken argues "With the valuable Eastern Coast fishery in jeopardy, the Massachusetts government commissioned a galley ship to protect its fishermen. The commander of the vessel, Joseph Majory, ranged the Eastern Coast, intercepting Acadian-owned boats and indiscriminately attacking Mi'kmaq people." 57

These attacks were premised upon assumptions that the Mi'kmaq passively followed Acadian Jesuit orders to engage in skirmishes with the Crown. Responding to this contention, Paul writes that during the negotiations that completed the Compact, “...Council members went out of their way to lay blame for past Mi'kmaq hostility towards the British King and his subjects upon the shoulders of the Acadians, especially the missionaries. Never once did they acknowledge that some of their own actions, e.g, holding elders and other Mi'kmaq hostage and taking their lands had contributed to Mi'kmaq animosity." ${ }^{28}$

\section{COMPLETING THE WABANAKI COMPACT}

\section{A. Dummer's Treaty}

With the Crown's concerns regarding threats to the Atlantic Cod trade, many believed that keeping the war alive throughout the region would lead to greater tactical and strategic blunders that would have disrupted expansionary interests. This understanding led the Crown to commission several treaty delegations to Wabanaki villages across the region, conveying an interest in engaging in treaty negotiations. The Crown was motivated to complete negotiations very quickly so as to remedy potential losses to the fishery while guaranteeing the release of Mi'kmaq and Wulstukwik captives. Reid writes that concluding the war largely came with the understanding that while "Colonial populations were larger and denser in the British colonies of the eastern seaboard, as late as the early decades of the $18^{\text {th }}$ century there were very few areas where - whether through trade, diplomacy or military force - Aboriginal nations were truly incapable of making their influence felt." ${ }^{, 59}$ Early negotiations took place in Boston in the Spring of 1725 and only Penobscot envoys directly participated.

Upon hearing of the Crown's aspirations to engage in treaty negotiations, Penobscot envoys travelled to Massachusetts as messengers for additional Wabanaki tribes who were unable to immediately participate. Patterson argues that "New England officials wanted peace treaties that would embrace all of the tribes with which they were in conflict, and they hoped that the Penobscot would serve as middlemen, speaking for others in negotiations and using their network of couriers and their system of diplomacy to bring all the others in." 60 Nevertheless, Wabanaki groups were not to be spoken for without being directly engaged in negotiations that most directly impacted their lived interests. These concerns led to the later agreements and ratifications that eventually completed the Wabanaki Compact.

56 Ibid at $14-15$.

57 William Wicken (1993) “'26 August 1726: A Case Study in Mi’ Kmaq - New England Relations in the early $18^{\text {th }}$ Century" 23 Acadiensis 5 at 19 Wicken supra note 8 at 96.

58 Daniel N Paul, We Were Not The Savages: Collision between European and Native American Civilizations: Third Edition (Black Point, Nova Scotia: Fernwood Press, 2006 at 93).

59 John Reid, "How wide is the Atlantic Ocean? Not Wide Enough!” (2005) 34 Acadiensis 84.

60 Patterson, “Anatomy”, supra note 3 at 48. 
Throughout the initial negotiations in Massachusetts ${ }^{61}$, the Penobscot envoys consistently pointed out that they would only serve as messengers and would not negotiate as representatives for Wabanaki tribes. Moreover, the Penobscot delegation would alert other tribes on the stipulations included in the proposed agreements but would not advocate that they accept any additional terms. The Crown viewed the Penobscot's insistence that they were only serving as messengers to be a great hindrance to their expansionary goals in the region. ${ }^{62}$ This is because the Crown regarded these agreements as unilateral land exchanges and encouraging their quickest completion better served their immediate interests. Reid argues "The stresses imposed by colonization during this crucial transitional era were unprecedented, with the settlement of non-Native populations characterized by land hunger and profound sense of entitlement." ${ }^{\prime 63}$ The completed agreements also showed major differences in how Wabanaki tribes looked to deal with settlement across the region.

Crown motivations to quickly complete the agreement had the Penobscot serving as unwilling representatives on behalf of Wabanaki tribes across the region. Patterson adds that the Penobscot participated so as to ratify earlier agreements and while they "acted for others in all of these exchanges, they had previously made it clear that they were facilitators of the process, and were making no final commitment for Native groups who had not yet seen the instruments." ${ }^{64}$ The Penobscot envoys only agreed to travel throughout the region and spread the news of the agreement. Their unwillingness to directly represent Wabanaki tribes beyond Massachusetts left the Crown to negotiate many agreements on their own.

The treaty completed in Boston in 1725 between the Crown and the Penobscot envoys later became known as Dummer's Treaty. This treaty was largely built upon the prior New England land agreements completed between 1675 and 1690. These agreements created a land sharing system that restricted the Crown's expansionary interests by preserving Penobscot and Passamaquoddy territorial integrity in the region. A key provision in Dummer's Treaty specifically relates to this treaty history by stating:

That His majesty's Subjects and the English Shall and may peaceably and quietly enter upon and improve and forever enjoy all singular Rights of God and former settlements properties and possessions within the Eastern parts of the province of Massachusetts Bay...Saving unto the Penobscot, Naridgwalk and other Tribes within his Majesty's Province Aforesaid and the natural Descendants respectively all their lands, Liberties and properties not by them convey'd or sold to or possessed by any of the English Subjects as aforesaid... ${ }^{65}$

61 Negotiations were initially held in Boston in the Fall of 1725. It could be generally assumed that the Penobscot participated early because their homelands stretched through present day Maine.

62 Ironically, some have argued the French looked to preserve some vestiges of Wabanaki sovereignty because it gave them a territorial barrier to protect against English Crown expansion in Quebec.

63 John G. Reid, "Empire, the Maritime Colonies, and the Supplanting of the Mi'kma'ki/Wulstukwik 1780 - 1820" (2009)

38 Acadiensis 92.

64 Patterson, "Anatomy" supra note 3 at 44.

65 Ibid at 54. 
Patterson argues Dummer's Treaty contained many stipulations that impacted generational Crown Indigenous relations in Massachusetts and Maine, but not in Nova Scotia. He goes on to point out that "All governors were instructed by the Crown to treat with native peoples, but they had considerable discretion in how they did so. They were expected to follow the advice of their councils, however, and in this case of Massachusetts and of Nova Scotia had quite different agendas. In a word, local needs and circumstances always were to shape how governors serve the Crown." 66

\section{B. Mascarene's Treaty}

Mi'kmaq and Wulstukwiuk groups had not negotiated earlier treaties largely because the French continued to exert substantial influence in the region. Moreover, initial attempts to integrate the Mi'kmaq into the jurisdictional regime sanctioned by the Treaty of Utrecht were met with resounding failure. Disagreements concerning territorial authority consistently emerged in treaty negotiations. Reid argues that in these agreements "Diplomacy meant that respect, formality and protocol must be maintained, but it did not demand that native representatives be drawn into the fiction that 'Nova Scotia' was British territory. The more absurd of British pretensions could thus be politely ignored." 67 With the Penobscot denying a role as representative on behalf of all Wabanaki tribes, Nova Scotia Lieutenant Governor Paul Mascarene was left with no choice but to directly encourage Mi'kmaq and Wulstukwiuk communities to accept the proposed treaty stipulations.

Mascarene's Treaty is an overarching title given to several agreements that included Wabanaki tribes across Nova Scotia and New Brunswick between 1726 and 1728. By 1728, up to 77 chiefs and other leaders accepted the proposed treaty terms. Negotiations between Paul Mascarene as well as many other Mi'kmaq and Wulstukwiuk chiefs once again hinged on submission to Crown authority, especially given the earlier relinquishment of Acadia to the British in the Treaty of Utrecht. In contrast, the Mi'kmaq and Wulstukwiuk consistently asserted authority to govern their customary territories as they believed appropriate. Nicholas points out that "Among the articles Mascarene was to demand was one insisting on Native submission to British law, another requiring Native agreement that 'the British King, his heirs and successors' are 'the sole owners... of Nova Scotia'... In effect, Native people were to be asked to surrender both their lands and their inherent authority to govern themselves." 68

Moreover, treaty histories in Nova Scotia were hardly as developed as the agreements that took place in New England decades earlier. This is the primary reason why the Mi'kmaq and Wulstukwiuk treaties are mentioned the Treaty of Utrecht while Dummer's Treaty only highlighted the 1675 to 1690 agreements. Consequently, treaty stipulations that guaranteed the Crown territorial authority akin to that maintained in the Treaty of Utrecht remained especially prominent in the agreement. One provision asserts

And we further promise on behalf of the said tribes we represent that the Indians shall not molest any of his majestie's (sic) subjects or the dependants (sic) in their settlements already made or Lawfully to be made, or in their carrying on their traffick (sic) and other affairs within the said Province. ${ }^{69}$

\footnotetext{
66 Patterson, supra note 3 at 54-55.

67 Reid, supra note 47 at 116.

68 Nicholas "Mascarene's Treaty", supra note 4 at 7.

69 Patterson, "Anatomy”, supra note 8 at 54.
} 
While many Mi'kmaq, Wulstukwiuk, Passamaquoddy and Penobscot representatives were among the 77 signatories to the eventual agreement, Patterson has argued that its validity can be questioned, given that many who initially accepted the agreement went on to summarily violate its terms, rendering it legally irrelevant in the present day.

\section{THE APPARENT INVALIDITY OF THE WABANAKI COMPACT}

\section{A. Persisting Conflict}

While many Wabanaki tribes accepted the treaty stipulations, it has also been argued that many more tribes were hardly aware that the agreement even existed. In ongoing raids on New England fishing vessels that took place after the agreement, Mi'kmaq individuals were captured and brought to trial. Upon being brought to trial many argued that they were unaware of any agreements affecting their villages, largely because they claimed to never be directly engaged by Crown envoys. Moreover, Mi'kmaq individuals who were captured by the Crown in raids that occurred during Dummer's War had not been released after Mascarene's Treaty was completed. In writing about one such judgment, Wicken points out "The Mi'kmaq defendants in 1726 also said that they were unsure whether a peace had been signed. In his deposition, (Mi'kmaq man) John Missel is recorded as saying that he heard from some Indians that there was peace but that others said 'they wondered...if there was Peace, (as) they (the English) did not bring the Indian Prisoners from Boston." ${ }^{, 70}$ Moreover, given earlier relations with the French and their anger over the Treaty of Utrecht, many Mi'kmaq and Wulstukwik went on to either ignore the agreement or leave it unsigned. It was believed that treaty stipulations went ignored or unsigned because the Mi'kmaq and Wulstukwiuk took part in continued skirmishes and raids against the Crown.

Ensuring treaty stipulations were accepted throughout the region was a difficult endeavour. After Mascarene's Treaty, many Mi'kmaq raids left some Wulstukwik and Wabanaki tribes offended by the actions of their neighbors. In subsequent decades, Patterson also points out that, "when another colonial war did break out between Britain and France in 1744, the Mi'kmaq and (Wulstukwiuk) quickly resumed their open support of France. Officials in Quebec ranked the Mi'kmaq first among all of their Native allies in America, and official journals catalogued the scouting, raiding and other activities of native warriors." 71 These continued engagements were believed to make Masarene's Treaty invalid largely because they went against key provisions that limited Mi'kmaq and Wulstikwiuk attacks on pre existing and eventual Crown settlements throughout the region. Moreover, Mi'kmaq and Wulstukwiuk parties resumed partnerships with Acadian traders and French Governors even after the agreement was completed, renewing the hostilities with the Crown until later treaties were negotiated in subsequent decades. Patterson even goes on to write "it was the British rather than the natives who looked for continuity in the treaty relationship; the natives believed that treaties broken were behind them, probably broken because they were "not upon a good footing."'72 Apparently, this good footing was only created nearly four decades later, when the the Crown asserted total control over what is presently Canada, in the Seven Years War, and went on to negotiate the 1760-61 Peace and Friendship Treaties with the Mi'kmaq and Wulstukwiuk.

\footnotetext{
70 Wicken "Relations" supra 59 at 19.

71 Patterson, "Experience", supra note 11 at 61.

72 Ibid at 62.
} 
As mentioned earlier, Patterson has argued the only legal validity accorded to the Atlantic treaties emerged in the Mi'kmaq and Wulstukwiuk accepting a place as subjects in the Crown's legal order. Any agreements that remained incomplete or became invalid through additional conflict left Indigenous groups turning "back the clock to 1500 " in isolation. He goes on to argue that in negotiating agreements through the late $18^{\text {th }}$ century, Mi'kmaq and Wulstukwiuk envoys who participated in treaty arrangements went on to acknowledge that prior agreements like Mascarene's Treaty and the 1752 Mi'kmaw Compact were violated and that a stronger base on which to establish new treaty partnerships was needed. This is largely because British victory in Seven Years War left the Mi'kmaq and Wulstukwiuk's partnership with the French strategically untenable. Given that earlier treaty agreements were broken because of longstanding ties to the French, Patterson contends that it was highly unlikely that they would be relied on to instruct new negotiations with the English.

Patterson argues that earlier broken agreements were highlighted so as to strongly encourage the Mi'kmaq and Wulstukwiuk to accept present treaty stipulations and hold strong to the obligations contained in new agreements. Patterson writes that later treaties depended upon the Mi'kmaq and Wulstukwiuk being obligated “...to accept British sovereignty, resolve misunderstanding 'according to the Laws establish in his said Majesty's Dominions,' and confine their trade to designated truckhouses. All these things, as the British understood them, required a Native acceptance of the prevailing laws of the province." 73

Patterson also points out that it remains a historical impossibility to read customary negotiating protocols $^{74}$ into the Wabanaki Compact. He goes to argue that while "There have been $20^{\text {th }}$ century arguments to the effect that all of the Nova Scotia treaties together represented a 'Covenant Chain', implying that all treaties were linked and remain valid, but there is no historical evidence to support this claim, while the concept of a 'Covenant Chain' itself - is an unjustified misuse of the term." "75 These assertions are troublesome because they leave historical Wabanaki groups caught between dueling English and French interests without the ability to exercise any agency beyond their dependency on these colonial powers.

Moreover, Patterson points out that the Mi'kmaq and Wulstukwiuk completely acquiesced to each stipulation developed by the Crown largely because they could not sufficiently maintain their own wellbeing without them, especially given the proposed trading partnerships in the region. He writes "The Aboriginal people were not the same as those who first met Europeans along the shore around 1500. They now hunted using European firearms, and relied on trade and, more recently, alliance in order to acquire European goods."76 With these conclusions, Patterson argues that the Mi'kmaq and Wulstukwiuk exchanged their territorial autonomy for greater trading relationships with the Crown as well as being granted a place as subjects in their legal order.

More importantly, Patterson's argument is premised on a view that treaty agreements can only maintain legitimacy when territorial autonomy is exchanged so as to be granted a place in the common law. Anything that violated these stipulations, whether through continuing military skirmishes or through an apparent lack of knowledge about the treaties, left the agreements completely invalid. He goes on to argue

\footnotetext{
Supra note 15 at 48.

Specifically those of the Haudensaunee (Iroquois) Confederacy.

Patterson "Experience", supra note 11 at 64.

Patterson, "Anatomy" supra note 3 at 51.
} 
that, in looking beyond earlier treaties, "the treaties of 1760-61 represented a new departure in treatymaking. They not only established the relationship of Mi'kmaq, Wulstukwiuk, and the Passamaquoddy with the Crown, without reference to the past, but, unlike previous experience, they seemed to work. Subsequent history shows that both Natives and non-Natives viewed 1760-61 as the cornerstone of their relationship." 77 In later agreements like the 1760-61 Peace and Friendship Treaty it appears as though the Wabanaki Compact (specifically Mascarene's Treaty), contained absolutely no legal validity. This opinion, Patterson contends, is mutually agreed upon by the Wabanaki and the Crown.

\section{B. Legal Invalidity of the Wabanaki Compact in the Case Law}

Patterson's arguments have been dealt with in legal judgments evaluating the continued validity of the Wabanaki Compact (specifically Mascarene's Treaty) as a guarantor of treaty rights throughout Nova Scotia, New Brunswick and Newfoundland. His arguments on the treaty's irrelevance have played an especially decisive role in judgments decided by Provincial Courts throughout the Atlantic region. In judgments like Newfoundland $v$. Drew, ${ }^{78}$ Patterson's argument that the Wabanaki Compact became legally "non - existent" through continued skirmishes and captures was explicitly taken up by the Court. This particular judgment asked whether or not Mi'kmaq groups living in Newfoundland's Conne River have a treaty right to build hunting cabins on provincial reserve territory. Building upon Patterson's claim that the Wabanaki Compact remained legally invalid because of persisting conflicts, Barry J., argues "French officials, particularly French missionaries, worked continuously to undermine Mi'kmaq adherence to the 1725-26 treaty. ${ }^{79}$ In August 1726, only two months after the signing of the treaty, a group of natives captured a Massachusetts fishing sloop at Mirligueche, Nova Scotia." ${ }^{80}$ This judgment specifically ruled that appealing to the Wabanaki Compact in Newfoundland was legally unworkable, given the disputed territories in the agreement and its questionable validity.

\section{THE LEGAL VALIDITY OF THE WABANAKI COMPACT}

\section{A. The Roots of Crown Obligation}

Patterson's argument is problematic given that he seemingly regards Mascarene's Treaty as being premised on a choice between legal recognition in English common law or detached isolation that "winds the clock back" to 1500 . Researching Mi'kmaq and Wultstukwiuk analyses on treaty agreements, particularly relating to Mascarene's Treaty, it is more likely that they looked to create equal partnerships with the Crown. These partnerships preserved their territorial autonomy while also inaugurating the British into a treaty order that respected their pre -existing settlements in the Atlantic region. Moreover, many have pointed out that treaty orders were built upon customary governing protocols that preserved interrelated well-being throughout ecological and cosmological orders. These eternal interdependent relations are believed to have greatly impacted the entire treaty order developed in the Wabanaki Compact in general and Mascarene's Treaty in particular.

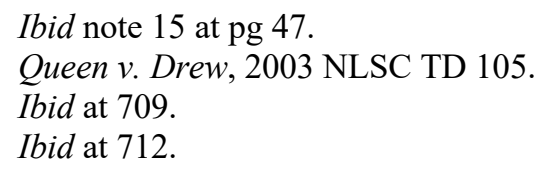


Among the Mi'kmaq and Wulstukwiuk, treaties were to hold the Crown subject to the interrelated obligation that already bound diverse communities to the Wabanaki Confederacy. The treaties were meant to inaugurate long lasting partnerships built on respecting Wabanaki autonomy and pre-existing Crown settlement. ${ }^{81}$ The treaty order regarded allied well being as absolutely imperative. Henderson also points out that

The order illustrates the development of a voluntary transnational law that was not based on the family structure. Instead the order was based on consensual agreements (emphasis added) among the Indigenous federations and European monarchies. ${ }^{82}$

During the negotiation of the Wabanaki Compact, conflicts pertaining to the assertion of Crown authority in the Wabanaki regions emerged. Henderson mentions that while "The Wabanaki Compact acknowledged the Wabanaki tribes were friends and subjects of the King, the British treaty commissioners candidly admitted they were not successful in getting the tribes to recognize King George as the sole owner and proprietor of New England and Nova Scotia." ${ }^{83}$ In essence, the Wabanaki negotiators and delegates recognized Crown authority over the English, but also affirmed that the King had no unilateral governing authority over the entire Dawnland as well as the Wabanaki tribes residing there for millennia. ${ }^{84}$

Thus, while Mascarene's Treaty contains many stipulations that seemingly granted the Crown supremacy throughout the region, many other agreements completed with the 77 Wabanaki partners, went to challenge this supremacy. Nicholas argues that Nova Scotia's Lieutenant Governor Paul Mascarene participated in many oral and written agreements that specifically acknowledged Wabanaki cultural rights as well as hunting, fishing and trapping rights. ${ }^{85}$ These agreements are collectively known as Mascarene's Promises. These Promises specifically contain the stipulation

I (Mascarene) do in behalf of His Majesty’s Said Governour (sic) and Government of Nova Scotia or Acadie - promise the said tribes all marks of Favoured protection and Friendship and further Ingage (sic) and promise on behalf of the Said Government That the Indians shall not be molested in their persons Hunting, Fishing and Planting Grounds nor in their Lawfull (Sic) Occassions (sic) by his Majesty's Subjects or their Dependants (sic) nor in the exercise of their Religion. ${ }^{86}$

While these stipulations bound the Crown to respect Wabanaki autonomy throughout their lands, they did not unilaterally emerge through the British acting to will these rights into being. They were an explicit recognition of the customary value the Wabanaki bestowed upon their territories throughout the ages.

81 Ibid at 215.

$82 \quad$ Ibid at 238.

83 Henderson, "Tenure" at 244.

84 James (Sakej) Henderson, "The Impact of Delgamuukw Guidelines in Atlantic Canada" (1999)

$<$ https://www.cbu.ca/indigenous-affairs/unamaki-college/mikmaq-resource-centre/essays/impact-of-delgamuukwguidelines-in-atlantic-canada/>.

85 Nicholas, "Mascarene's Treaty", supra note 4 at 10.

86 Ibid at 17. 
Henderson goes on to assert "The Mi'kmaw treaties with the British kings did not bestow upon the Mi'kmaq any rights...rather the Mi'kmaq gave certain rights to the British king for the benefit of British settlers in Mi'kmaw territories. In the treaties, the Mi'kmaq retained sovereignty, law, their knowledge system, freedom of religion and their territory for themselves; they never granted the kings any power over those ancestral rights." 87

Nicholas goes on to assert that these rights "....comprise nothing more than what Natives enjoyed before the establishment of the English in Nova Scotia (peace and the right to share in the fruits of the land by hunting and fishing). With regards topracticing religion, Nicholas also writes that in completing Mascarene's Treaty “...the original demand for all missionaries serving Native people to have government approval is turned into an offer of freedom of religion providing priests are approved by the government. ${ }^{" 88} \mathrm{By}$ contrast, the benefits to the English from this treaty were to be much greater than they had hitherto enjoyed (the right to share the land in peace)." 89

The Crown accepted Wabanaki sovereignty on the condition that their settlements would not be threatened by raids or skirmishes. This implied that the English were equally obligated and bound by Mascarene's Treaty on a level similar to the Wabanaki, given their assent to Indigenous autonomy. In the event that the treaty was broken through unending conflicts, the Crown had an equal role in repairing the damage done, well beyond assessing what the Wabanaki had done to "disrupt" the agreement. ${ }^{90}$ Given that obligation was equally held among each treaty party, it could not be only the Crown that decided when a treaty commitment had not been lived up to; especially given that Mascarene's Promises accepted Wabanaki autonomy across the region as a preliminary condition on which to maintain Crown settlements. The Wabanaki people regarded these obligations as indicators that the Compact remained unbroken.

\section{B. Ceremonial Remedies to Treaty Violation}

In attempts to stop conflicts and to live up to Mascarene's Promises, the Crown initially looked to uphold the treaties through gift giving ceremonies. Reid writes that "in terms of the ability to make diplomatic use of armed capacity, another process drew upon a long established pattern of Native-imperial relations in Mi'kma'ki and Wulstukwiuk that extended backwards in time through the treaty making years and beyond." ${ }^{1}$ These processes were the ceremonial and gift giving guarantees observed in the years succeeding the Compact.

Ceremonial gift giving events were especially crucial in satisfying treaty obligation even in the event of prolonged armed conflict. They served as an ideal dispute resolution method on which to hold treaty parties accountable for not upholding their responsibilities. Nicholas argues "Even outbreaks of violence by one side or the other cannot justify termination when a mechanism of dispute resolution is built into

87 Henderson supra note 20 at $101-102$.

88 Nicholas, "Mascarene's Treaty", supra note 4 at 10.

89 Ibid.

90 Analyzing treaties with the Confederative principle in mind implies that Nations could hold normative autonomy while also collectively holding obligation to preserve living treaty relationships throughout future generations. Relational ties among nations aligned in a Confederacy are premised on a strong responsibility to preserve and assist the well being of adjoined communities or nations.

91 Reid, "Supplanting” supra note 68 at 96. 
the treaty." 92 Ceremonial events were largely an opportunity to remedy a treaty violation, with both treaty parties restating their commitment to live up to their obligations. Moreover, gift giving was also believed to hold parties in equal standing and to acknowledge that "treaties are statements of reciprocal obligations which, once made, are entrenched, have the force of law, and cannot be terminated by one party unilaterally, or by anyone who is not a party to the treaty." 93 For instance, a 1725 letter written by Nova Scotia Governor Laurence Armstrong and addressed to Paul Mascarene asserted that proper negotiations were to be upheld through proposals of peace emanating among both the Crown and the Wabanaki. This letter specifically stresses:

You (Mascarene) are to acquaint the Govr. \& Council That I am Daily in Expectation of hearing from the Indian Chiefs on this side, and of Receiving their proposalls (sic) for Peace. $^{94}$

Receiving these proposals implied that the Crown was to ultimately regard the Wabanaki as equal to the British in upholding treaty obligation. Ceremonies were meant to uphold these obligations by restating continued commitment to the treaty order.

Peaceful relations were to be maintained by guarantees that the Crown would never assert any sovereign demands over the Wabanaki throughout the region. Lennox asserts that, "in lieu of a sovereign power, there developed in Nova Scotia a system of territorial checks and balances in the form of shared spaces that enabled these various groups to interact peacefully, resolve conflicts through negotiation, and maintain an acceptable division of geography during a period of contested dominium and a complete lack of imperium." 95

Ceremony was always acknowledged as a process instead of a singular event, and the Wabanaki Compact encouraged innovative approaches on which to uphold the treaty order. One particular approach was observed through gift giving. While the Compact guaranteed treaty partners' existence as autonomous political bodies, each party agreed to live up to the treaty order through observing these customary ceremonies. Participating in these ceremonies ensured that the Crown became a valued trading partner and ally. The Wabanaki also upheld their roles as territorial guardians, ceremonial heads and allies. Akin to the ceremonial "brightening" of the Covenant Chain in the Haudensaunee Confederacy, ${ }^{96}$ the Wabanaki Confederacy and the Crown would participate in these ceremonies to re-affirm commitments to the collective prosperity of the Dawnland of which the British were to be a part.

The impact these ceremonial conventions had (and still have today) on the Wabanaki is not to be underestimated, especially given the generational significance communities have attached to ceremonial practices like gift giving. Henderson points out that gift giving ceremonies were an opportunity to establish the Crown's place in the treaty order. He writes 'In order to 'Cherish a good Harmony' created by the

92 Nicholas, "Mascarene's Treaty", supra note 4 at 5-6.

93 Ibid at 5.

94 Ibid at 14.

95 Jeffers Lennox (2015) "Time and a Place: The Geography of British, French, and Aboriginal Interactions in early Nova Scotia" 72 The William and Mary Quarterly 3 at 429.

96 Mark D. Walters, "Brightening the Covenant Chain: Aboriginal Treaty Meanings in Law and History After Marshall" (2001) 24 Dalhousie L.J. 75 at 80. 
new relationship, the Crown promised that 'so long as they shall Continue in Friendship', the Mi'kmaw would annually receive 'Present of Blankets, Tobacco, some Powder \& Shott'. These provisions were consideration for British settlements and trading rights with the Mi'kmaq." ${ }^{\prime 97}$ Wicken also writes that potential interpretive conflicts between negotiators and envoys would "...underline the importance of community meetings which, either intentionally or not ensured a common understanding of treaty relationships...this is shown by the annual reading of original treaties and agreements at social and political congregations. $" 98$

The symbolic value attached to treaty obligation through events like gift giving was evident through the oral testimony delivered by Mi'kmaq Grand Chief Gabriel Syliboy during the $1929 R$ v. Syliboy judgment. ${ }^{99}$ This judgment occurred two centuries after the Wabanaki Compact. In sworn oral testimony gathered by Wicken, Sylliboy points out the generational importance the Mi'kmaq attached to the treaty agreements. During the trial, he asserts "Since I was boy heard that Indians got from King free hunting and fishing at all times. Still believe treaty good. Under treaty get gov't blankets and flour and some shoes \& long coats. Still get them. Gov't put up \& maintain schools on every reservation. Putting up Home at Shubenacadie. ${ }^{100}$ All by virtue of Treaty." ${ }^{\prime 101}$ For the Wabanaki, Crown loyalty to the treaty order extended well beyond the immediate needs and demands of whoever lived during the Compact's completion. Every potential benefit gifted to the Crown (through voluntary land cession, trade and ceremonial agreement) on behalf of the Wabanaki Nations was to always depend on the Crown's willingness to respect their autonomous well being.

\section{Interrelated Obligation in the Case Law}

Many later judgments throughout the decades have maintained the continued validity of the Wabanaki Compact and specifically Mascarene's Treaty. ${ }^{102}$ These Provincial judgments mainly argue that the Compact remains a vital source to secure customary rights to activities like logging on Crown territory. ${ }^{103}$ In a series of judgments in $R v$. Sappier and Polchies, the New Brunswick Provincial Court and Court of Appeals argues that Mascarene's Treaty guaranteed Wulstukwiuk loggers a right to harvest timber on

97 Henderson "Tenure" supra note 20 at 254.

98 William Wicken, "'Heard it From our Grandfathers': Mi' Kmaq Treaty Tradition and The Syliboy case of 1928" (1995) 44 U.N.B.L.J 145., (HO) Continued traditions like St. Anne's Day, the recent inauguration of Mi' Kmaw Treaty Day and the annual gatherings of Wabanaki Nations throughout the Dawnland are an example of the eternal value accorded to ceremonial customs.

99 Although this judgment specifically concerned the 1752 Mi'kmaw Compact, the connection between gift giving ceremony and preserving the treaty order is evident.

100 Now known as Sipekne'katik First Nation, it is located in what is now central Nova Scotia.

101 Wicken supra note 102 at 158.

102 These judgments largely build on the trajectory established on crucial Supreme Court and Court of Appeals judgments including (but not limited to) Simon v. The Queen, (1985) 2 SCR 387, $R$ v. Denny 19902412 (NS CA), R v. Sparrow, (1990) 1 SCR 1075, $R$ v. Badger (1996) 1 SCR 771, $R$ v. Sundown, (1999) 1 SCR 393, $R$ v. Marshall, (1999) 3 SCR 456, $R$ v. Marshall (1999) 3 SCR 533, $R$ v. Marshall; $R$ v. Bernard, (2005) 2 SCR 220, 2005 SCC 43.

103 This was previously established in earlier judgments like Simon where the Supreme Court ruled that the right to hunt embedded in the Mi' Kmaq Compact (1752) contained sui generis legitimacy past any historical and political contingency or continued hostility between the Crown or Mi'kmaq. 
Crown lands so as to build homes and to give away firewood. ${ }^{104}$ At the Provincial Court, Cain J denied the assertion that the treaty vested all the Wulstukwiuk's landed interests to the Crown. Given that living members of the Woodstock First Nation were descendants of original treaty signatories, it was argued that their harvesting activity remained crucial in sustaining collective physical and cultural well-being. It was argued that respecting these rights built up partnerships where each treaty signatory would be regarded as equally crucial to the agreement's continued validity. Cain J., argues that Mascarene's Treaty "demonstrated a desire of the several parties to go some length to seek harmony and peace, and is evidence of the 'mutual respect and esteem' between the Signatories." 105 This judgment was strongly supported upon reaching the New Brunswick Court of Appeals one year later.

When rehearing Sappier and Polchies ${ }^{106}$ at the New Brunswick Court of Appeals, Robertson J., goes on to assert that the Provincial Court's judgment on the treaty's validity is "unassailable." 107 This is because a treaty right to harvest timber was believed to evolve depending on how living conditions among the Wulstukwiuk had changed since Mascarene's Treaty was originally agreed upon. Rather than being an evolution that was antithetical to the original treaty right, it was pointed out that any activity using timber to craft a 'furnishing' related to cultural well-being was protected by the treaty. Robertson J., argues "I am of the view that construction of a bungalow constitutes a modern day expression of a 1725 treaty right to harvest wood for purposes of constructing a wigwam. Similarly, the construction of furniture is a modern expression of the ancestral practice of crafting 'rude furnishings' from wood, as part of the (Wulstukwiuk's) $18^{\text {th }}$ century lifestyle."108

These judgments went on to be upheld by the Supreme Court two years later in $R v$. Sappier; $R v$. Gray. ${ }^{109}$ While the Court pointed out the Crown's concessions regarding the validity of the Wabanaki Compact, ${ }^{110}$ Henderson argues "The Supreme Court affirmed here that the Mi'kmaq (and Wulstukwiuk) enjoyed Aboriginal rights as communal rights, to engage in logging on Crown lands for 'personal use' as opposed to commercial purposes."111 These judgments largely built upon the earlier Supreme Court opinion in Sundown. This ruling concerned the legality of a Cree man erecting a dwelling on provincial parkland. The Supreme Court went on to decide that preserving traditional Cree expeditionary styles of hunting (which required a dwelling) did not imply claiming property against the state, but rather fidelity

104 R. Sappier and Polchies 2003 NBPC 2

105 Ibid.

106 R. Sappier and Polchies 2004 NBCA 56

107 Ibid at para 1.

108 Ibid at para 19.

109 See $R$ v. Sappier; $R$ v. Gray, 20062 SCR 686, 2006 SCC 54.

110 In Para 64 of Sappier/Grey, Bastarche,.J. writes "These issues, along with the validity of the 1725 Treaty, were recently the subject of judicial consideration in the Province of Newfoundland and Labrador. In Newfoundland $v$.

Drew (2003), 228 Nfld. \& P.E.I.R. 1, 2003 NLSCTD 105 (CanLII), the trial judge concluded that the 1725-1726 Treaties have no legal force insofar as they were terminated by subsequent hostilities between the Mi'kmaq and the British. Alternatively, he held that the 1725 Treaty by its express terms did not apply to Newfoundland, and that, in any event, the scope of the Treaty should be interpreted as restricted to territory within the jurisdiction of the Governor of Nova Scotia. An appeal from that judgment was dismissed by the Newfoundland and Labrador Court of Appeal" .

111 James (Sa'ke'j) Youngblood Henderson, "Alexander Denny and the Treaty Imperative" in Marie Battiste, eds, Living Treaties: Narrating Mi'Kmaw Treaty Relations (Sydney, NS: Cape Breton University Press, 2016) 112. 
to traditional Indigenous rights. More specifically, In Sappier/Polchies as well as Sappier/Grey, treaty rights were argued to include customary logging practices in creating "rude furnishing."

While the Supreme Court judgment only encouraged a limited right to logging for customary purposes, these judgments are crucial in advancing the argument that the Wabanaki Compact has always remained legally relevant. ${ }^{12}$ This is because they were each based upon the assertion that the Compact was meant to respect the Wabanaki tribes' customary ability to maintain their cultural and physical well being throughout the generations. They also bestowed an obligation on the Crown to not disrupt or limit their exercise of these rights. Nicholas, serving as an expert witness in the Madawaska Maliseet First Nation ${ }^{113}$ judgment, makes this very clear by arguing

The Treaty of $1725 / 26$ became a template upon which successive treaties were built. It was not only about peace and friendship, but about mutual respect for two very different modes of life and land use. It also meant that we would respect the settlements that resulted. The English on the other hand agreed in the treaties to respect us in our hunting, fishing, and planting grounds. This was an implicit commitment to respect our mobile form of life...The treaty clearly stated that neither party would molest the other in their respective forms of life, and that only in this way could peace prevail. ${ }^{114}$

\section{CONCLUSION}

The types of partnerships the Wabanaki Compact encouraged were not to be tossed aside simply because it proved very difficult to move beyond the conflicts that led to Dummer's War. The Wabanaki (specifically the Mi'kmaq and Wulstukwiuk) looked to create treaty partnerships where parties would value each other as key to preserving the treaty order. While conflicts did ensue when attempting to uphold the agreements, the ceremonial and legal opportunity to guarantee reparations ensured that the Wabanaki Compact would not be swept away because one party believed it to be broken. Given that treaties extend obligation throughout generations there are always ways to re engage one's commitment to the partnership. The Wabanaki Compact (specifically Mascarene's Treaty) did not imply a choice between accepting Crown sovereignty or an eventual turn to complete isolation. The Compact encouraged generational obligation in which attempts to preserve long lasting partnerships through ceremony, gift giving and ultimately recognition through the courts, kept the treaty imperative as alive in the present day as it was in 1725 .

112 These judgments also move beyond a rigidly literal interpretation of treaties given that "The Honour of the Crown" guarantees that the Crown always act honorably in its dealing with Indigenous people. For instance, this includes maintaining treaty obligation with no sharp dealing. In Marshall (1999), the Supreme Court reasoned that the Honour of the Crown could only be maintained through a relatively broad interpretation of the right to trade, hunt and fish guaranteed in the $1760-61$ treaties, particularly when judging on their application in the present period. As Justice Binnie wrote: "The surviving substance of the treaty is not the literal promise of a truckhouse, but a treaty right to continue to obtain necessaries through hunting and fishing by trading the products of those traditional activities... (para 5)."

113 Madawaska Maliseet First Nation v. Her Majesty the Queen in Right of Canada, 2017 SCTC 5.

114 Ibid at para 34. 